\title{
Impacto e diferenças regionais do trote nos cursos brasileiros de medicina: análise qualitativa com diretores e educadores médicos
}

\section{Juliana Roberta M. Ragozzino (IC), Larissa Gomes Galas (IC), Milene Ioneda Sugiyama (IC), Maria Cristina Pereira Lima (PQ), Luís Fernando Tófoli (PQ)}

\section{Resumo}

Análise qualitativa de conteúdo da opinião de educadores médicos de todo o Brasil a respeito do trote universitário nas escolas médicas do país.

Palavras Chave: educação médica, violência, estudantes.

\section{Introdução}

O trote atualmente está ligado ao ingresso em cursos de Graduação - principalmente em Medicina - sendo relacionado à manutenção da hierarquia nesse meio acadêmico desde o século XVII. A partir da análise da literatura, ocorre uma preponderância regional de artigos e notícias na mídia do Sudeste brasileiro e escassa informação sobre as outras regiões. Este trabalho tem como objetivo de realizar uma análise qualitativa de conteúdo $^{1,2}$ das opiniões de docentes médicos de todo o país sobre o trote nas escolas médicas, as razões de sua existência, seus aspectos positivos e negativos e suas diferenças regionais no Brasil.

\section{Resultados e Discussão}

A partir de um survey online quali-quantitativo com 142 respondentes de 79 escolas médicas, foi selecionada uma amostra intencional com as respostas de 40 participantes, utilizando critérios que tinham como objetivo maximizar a variabilidade de conteúdo.

No que diz respeito ao motivo da existência e perpetuação do trote, observaram-se as visões de rito de passagem e de manutenção da hierarquia e tradição.

Ao analisarmos as respostas aos aspectos positivos, observamos maior diversidade como solidariedade e integração; e nos negativos, respostas condenando o trote violento. Houve também como resposta o relato de ausência de aspectos positivos neste fenômeno.

A opinião dos participantes acerca das diferenças regionais do trote suporta a noção de que o trote é mais violento em faculdades tradicionais e/ou região Sul e Sudeste, em especial as paulistas. Contudo, outra parte afirma não ter conhecimento sobre assunto.

Há relatos do trote ocorrer como "brincadeira" e de forma solidária e, também como humilhação e violência. Apesar disso, também se nota a opinião de que não haja necessidade de mudança, enquanto outra opinião vigente sugere a implantação de debates sobre tema.

\section{Conclusões}

A existência e perpetuação do trote são vistas por educadores médicos como rito de passagem e manutenção da hierarquia e tradição. Os participantes que expressam suas opiniões sobre variações regionais parecem reforçar a impressão de que o trote ocorra de forma desigual no país. As opiniões diversas sobre o trote e de seus aspectos positivos e negativos são discutidas neste trabalho, mas os resultados parecem indicar que o tema não se esgota aqui, e ainda deve ser estudado de forma mais aprofundada.

\section{Agradecimentos}

Instituição de Fomento: PIBIC/CNPq

\footnotetext{
${ }^{1}$ MORAES, Roque. Análise de conteúdo. Revista Educação, Porto Alegre, v. 22, n. 37, p. 7-32, 1999.

${ }^{2}$ HSIEH, Hsiu-Fang; SHANNON, Sarah E. Three Approaches to Qualitative Content Analysis. Qual Health Res, v. 15, n. 9, Nov. 2005, p. $1277-1288$
} 